\title{
Analisis Pengaruh Nilai Tukar Rupiah dan Laba Bersih Terhadap Kinerja Harga Saham Bank Panin Syariah
}

\author{
Riyan Pradesyah \\ Program Studi Perbankan Syariah Fakultas Agama Islam \\ (Email: rriyanpradesyah@yahoo.com)
}

\begin{abstract}
Abstrak
Penelitian ini bertujuan untuk mengetahui Pengaruh Nilai Tukar Rupiah, dan Laba Bersih Terhadap Kinerja Harga Saham bank Panin Syariah. Sampel yang digunakan dalam penelitian ini adalah data NTR, LBS terhadap Kinerja harga Saham bank Panin Syariah dari bulan Januari 2010 sampai Desember 2015. Pendekatan penelitian yang digunakan adalah pendekatan penelitian kuantitatif dengan analisis VAR (Vector Auto Regressive) yakni didukung uji stasioneritas, uji lag optimal, uji stabilitas model VAR, uji kausalitas granger, uji impulse respon function dan uji variance decomposition, dibantu dengan software Eviews versi 6.

Dari hasil penelitian yang dilakukan pada alpha 5\%, penulis menyimpulkan bahwa hasil analisis VAR yakni uji Varince Decomposition menunjukkan bahwa variabel Nilai Tukar Rupiah, dan Laba Bersih berpengaruh terhadap Kinerja Harga Saham bank Panin Syariah. Dalam jangka pendek atau periode awal pengamatan hingga akhir pengamatan, Laba bersih memiliki pengaruh lebih dominan sebesar 13,87\%. Sedangkan Variabel Nilai Tukar Rupiah memiliki pengaruh terhadap Kinerja harga saham sebesar 0,23\%. Dari hasil uji kausalitas granger menunjukkan bahwa semua variabel memiliki hubungan kausalitas satu sama lain, artinya setiap variabel memiliki hubungan 2 arah dengan variabel lainnya. Sedangkan hasil uji impulse response function menunjukkan bahwa Kinerja harga saham merespon positif dan seimbang terhadap Nilai tukar rupiah. merespon variabel laba bersih dengan negatif dan mendekati titik keseimbangan. Jadi, bila diuji secara bersamaan, variabel yang paling mempengaruhi adalah variabel laba bersih.
\end{abstract}

Kata Kunci : Nilai Tukar Rupiah, Total Penjualan, Laba Bersih, dan Kinerja Harga Saham

\section{A. Pendahuluan}

Perbankan syariah merupakan suatu lembaga keuangan yang beroperasi sesuai dengan prinsipprinsip islam. Atas dasar bagi hasil, bank syariah mulai dikenal dan diminati oleh kebanyakan masyarakat, bukan hanya di Indonesia saja, masyarakat luar negripun kini mulai mengembangkan perbankan syariah di daerah mereka masing-masing.Perkembangan perbankan syariah di Indonesia sejak tahun 1998, dimana pada waktu itu 
Indonesia mengalami krisis yang berdampak pada bank-bank konvensional, tetapi tidak pada bank syariah.Dari awal inilah bank syariah mulai dikenal oleh masyarakat Indonesia. ${ }^{1}$

Dimulai dari tahun 1998, bank syariah terus melihatkan eksistensinya untuk terus melaju dan berkembang di Indonesia. Banyaknya kemunculan bank-bank syariah di Indonesia, merupakan suatu bukti nyata, bahwa bank syariah mampu untuk bersaing dengan bank konvensional.Perkembangan bank syariah di Indonesia memang sangat cukup nyata, dilihat dari data yang telah di publikasikan oleh Bank Indonesia (BI).

Adapun informasi yang di dapat peneliti tentang nilai jual rupiah terhadap dollar amerika adalah sebagai berikut.

\section{Tabel.1. Data Nilai Tukar Rupiah}

\begin{tabular}{|l|r|}
\hline Bulan & \multicolumn{1}{|c|}{ Kurs Jual } \\
\hline Januari & $9,881.41$ \\
\hline Februari & $10,066.25$ \\
\hline Maret & $10,056.36$ \\
\hline April & $10,391.20$ \\
\hline Mei & $10,183.46$ \\
\hline Juni & $10,271.67$ \\
\hline Juli & $9,895.46$ \\
\hline Agustus & $10,058.21$ \\
\hline
\end{tabular}

${ }^{1}$ Ismail, Perbankan Syariah, (Jakarta : Kencana, 2014), hal. 31

\begin{tabular}{|l|r|}
\hline September & $10,322.78$ \\
\hline Oktober & $9,736.08$ \\
\hline November & $9,992.23$ \\
\hline Desember & $10,117.95$ \\
\hline
\end{tabular}

Sumber : www.bi.go.id

Menurut pengamat Ekonomi SUMUT, Gunawan Benjamin Pada saat nilai tukar rupiah melemah, Indeks Harga Saham Gabungan atau IHSG mengalami penurunan. Hal ini terjadi pada awal bulan September hingga pertengahan October 2015.Namun, pada saat nilai tukar Rupiah mulai membaik, di saat ini pula Indeks Harga Saham atau IHSG mulai diperdagangkan pada teoriteori positif. ${ }^{2}$ Tentu saja hal tersebut menunjukan bahwa adanya fenomena korelasi atau hubungan, antara nilai tukar rupiah, IHSG, total penjualan dan saham emiten (perusahaan) itu sendiri.

Disisi lain laba bersih juga dapat menganalisis atau melihat apa yang telah dilihat oleh Rasio Likuiditas, tentang seberapa baik kinerja keuangan suatu perusahaan dalam menghasilkan laba atau keuntungan. Nah, dari laba bersih inilah sebahagian atau seluruhnya dibagikan dalam retrun deviden (hasil investasi bunga saham atau hasil tranding saham).Pada saat itu pula deviden (bunga) mengalami kenaikan, yang pada umunya terjadi pada kenaikan harga sewa suku

${ }^{2}$ Wawancara dengan Pengamat Ekonomi SUMUT, di Reksa Dana, pada tanggal 14 oktober 2015. 
emiten (perusahaan).Terkait dengan hal tersebut, maka diduga adanya hubungan antara laba bersih dengan kinerja harga saham.

Terkait dengan fenomena yang ada di atas, Bank Panin Syariah telah mempublikasikan sebuah laporan keuangan yang dapat dilihat oleh siapapun yang membutuhkan informasi terkait atas perusahaan.Di dalam pempublikasian laporan keuang tersebut, bank panin syariah telah menginformasikan laba bersih yang diperoleh oleh perusahaan. Ketika peneliti melihat dan membaca laporan perusahaan tersebut, peneliti menemukan sebuah fenomena yang menarik pada laporan keuangan bank panin yang telah dipublikasikan dengan satuan miliar. Pada tahun 2013 sebelum terjadinya dampak terhadap nilai tukar rupiah terhadap dolar, laba perusahaan bank panin syariah telah mencapai Rp. 21,332, sedangkan pada tahun 2015 laba perusahaan bank panin mencapaiRp. 29,266 . Peningkatan laba terjadi pada tahun 2015, yang merupakan suatu penurunan terhadap nilai tukar rupiah terhadap dolar.Hal tentu saja membuat peneliti penasaran dan ingin meleiti tentang kinerja harga bank panin syariah, terkait dengan data yang telah di publikasikan oleh perusahaan bank panin syariah.

Dari fenomena yang dapat kita lihat diatas, peneliti tertarik untuk untuk meneliti tentang kinerja harga saham, yang peneliti rangkum dalam judul"Analisis Pengaruh Nilai Tukar Rupiah, dan Laba Bersih Terhadap Kinerja Harga Saham PT. Bank Panin Syariah"

\section{B. Perbankan Syariah}

Dalam dunia perbankan, kita telah mengenal bank konvensional dan bank syariah. Di mana, kedua bank tersebut mempunyai fungsi yang sama, yaitu menghimpun dan menyalurkan dana kepada masyarakat. Jika bank konvensional menggunakan sisitem riba, maka bank syariah mempunyai sisitem bagi hasil.Di mana, di dalam sistem bagi hasil tersebut telah disepakati oleh kedua belah pihak (Bank dan nasabah), dengan ketentuan yang telah disepakati. Adapun ayat AlQuran yang melandasi tentang perbankan syariah adalah Q.S.Al Baqara ayat 275
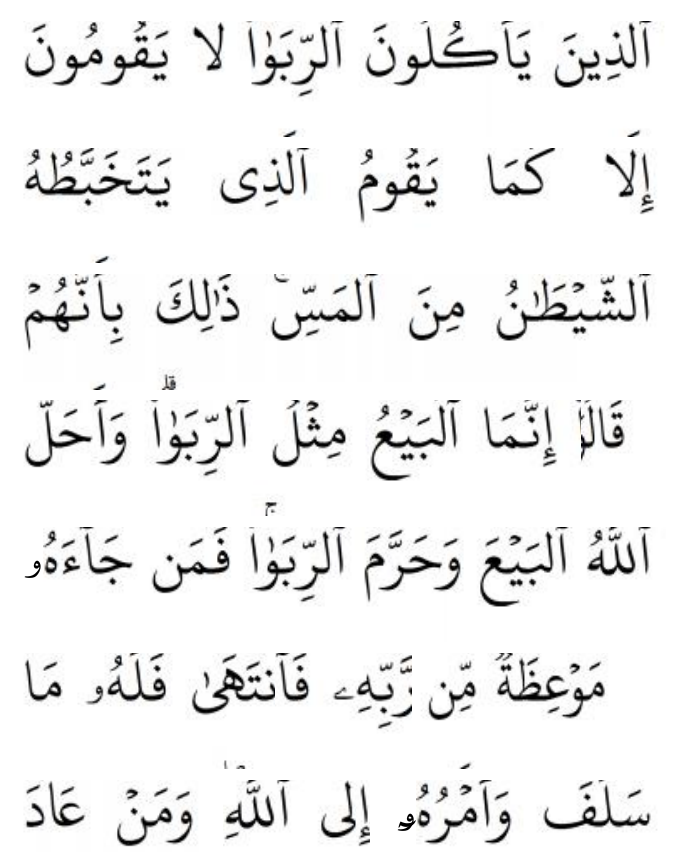


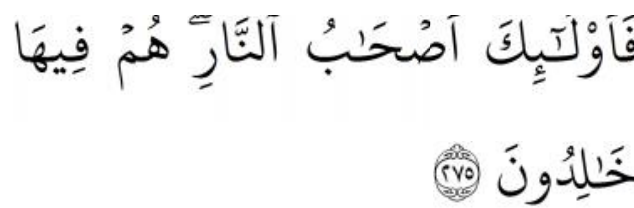

"Orang-orang yang makan (mengambil) riba tidak dapat berdiri melainkan seperti berdirinya orang yang kemasukan syaitan lantaran (tekanan) penyakit gila. Keadaan mereka yang demikian itu, adalah disebabkan mereka berkata (berpendapat), sesungguhnya jual beli itu sama dengan riba, padahal Allah telah menghalalkan jual beli dan mengharamkan riba. Orang-orang yang telah sampai kepadanya larangan dari Tuhannya, lalu terus berhenti (dari mengambil riba), maka baginya apa yang telah diambilnya dahulu (sebelum datang larangan); dan urusannya (terserah) kepada Allah. Orang yang kembali (mengambil riba), maka orang itu adalah penghunipenghuni neraka; mereka kekal di dalamnya" ${ }^{3}$

Berlandaskan Al-Quran dan hadits, bank syariah terus memperlihatkan kinerjanya dan mengembangkan produk-produk yang ada di dalam perbankan syariah tersebut. Terbukti, dari banyaknya bank-bank syariah yang bermunculan sampai pada sekarang ini.Kesuksesan dan pembuktian bank syariah terhadap Al-Quran

${ }^{3}$ Departermen Agama Republik Indonesia, Al-Quran dan Terjemahan, (Bogor : Sabiq),hal. 47 dan hadits, membawa perbankan syariah keranah dunia.Hingga pada akhirnya, bank syariah atau sisitem syariah banyak diminati masyarakat.Sebab, di dalam perbakan syariah, mempunyai prinsip saling tolong menolong.

Bank syariah juga memiliki arti yang telah dibakukan dalam Undang-undang No.10 tahun 1998 bank syariah adalah Bank yang melaksanakan kegiatan usahanya berdasarkan prinsip syariah yang dalam kegiatannya memberikan jasa dalam lalu lintas pembayaran

Pasal 2 Peraturan Bank Indonesia (PBI) No. 6/24/PBI/2004 Tentang Bank Umum yang Melaksanakan Kegiatan Usaha Berdasarkan Prinsip Syariah, memberikan definisi bahwa Bank umum syariah adalah bank yang melaksanakan kegiatan usaha berdasarkan prinsip syariah yang dalam kegiatannya memberikan jasa dalam lalu lintas pembayaran. Secara garis besar hubungan ekonomi berdasarkan syariah Islam tersebut di tentukan oleh hubungan akad yang terdiri dari lima konsep dasar akad.

\section{Nilai Tukar Rupiah}

Hubungan ekonomi antara negara yang melewati batas-batas suatu negara memerlukan suatu mata uang yang bisa dijadikan patokan umum. ${ }^{4} \mathrm{Hal}$ tersebut sering juga

${ }^{4}$ Emi Umi Hasanah, dan Dangan Sunyoto, Pengantar Ilmu Ekonomi Makro, (Jakarta : CAPS, 2012), hal. 119 
disebut sebagai nilai tukar atau kurs. Kurs mata uang adalahnilai sebuah mata uang negara tertentu yang diukur, dibandingkan, atau dinyatakan dalam mata uang negara lain. ${ }^{5}$ Misal kurs rupiah terhadap dolar Amerika, menunjukan berapa rupiah yang diperlukan untuk ditukarkan dengan satu dollar Amerika. Pertukaran kedua mata uang antara negara tersebut juga di sebut dengan Foreign exchange rate, adalah pertukaran antara dua mata uang yang berbeda, yaitu merupakan perbandingan nilai atau harga antara kedua mata uang tersebut. ${ }^{6}$ Misalnya dolar terhadap rupiah, dimana pada setiap penukaran setiap $1 \$=\mathrm{Rp}$. 1300, itu berarti rupiah terhadap dolar adalah 1 rupiah = 1/1300 dollar Amerika. hal ini juga disebut sebagai timbale balik nilai tukar mata uang. ${ }^{7}$

Di dalam sistem nilai tukar mata uang, kossep forign exchange rate dibagi menjadi dua macam, yaitu konsep hard curriencies (mata uang kuat) dan soft curriencies (mata uang lemah). ${ }^{8}$ Adapun ciri-ciri yang tergolong hard curriences adalah mata uang tersebut diterima luas

5 R. Serfianto dan D. Purnomo, Pasar Uang Dan Pasar Vals, (Jakarta : Gramedia Pustaka Utama, 2013), hal. 112.

${ }^{6}$ Triyono, Analisis Perubahan Kurs Rupiah Terhadap Dollar Amerika. Jurnal Ekonomi Pembangunan. Vol 9, No.2, 2008, Hal. 156.

${ }^{7}$ N. Gregeory mankiw, Pengantar Ekonomi, (Jakarta : Erlangga, 2000), hal. 328.

${ }^{8}$ Erni Umi Hasanah, dan Dangan Sunyoto, Pengantar Ilmu Ekonomi Makro, (Jakarta : CAPS, 2012), hal. 119 diseluruh dunia, pasa mata uang tersebut bebas dan aktif, dan restriksi atau hambatan yang relative sedikit.Sedangkan cirri-ciri soft curriences adalah mata uang tersebut tidak diterima secara luas sebagai mata uang dunia, tidak memiliki pasar uang valas yang bebas dan aktif, mata uang ini tidak mudah diperoleh.

Nilai tukar suatu mata uang dapat ditentukan oleh pemerintah (otoritas moneter) seperti pada negara-negara yang memakai sistem fixed exchange rate ataupun ditentukan oleh kombinasi antara kekuatan-kekuatan pasar yang saling berinteraksi (bank komersialperusahaan multi nasionalperusahaan manajemen assetperusahaan asuransi- bank devisabank sentral) serta kebijakan pemerintah seperti pada negaranegara yang memakain rezim sistem flexible exchange rate. ${ }^{9}$

Kurs atau nilai tukar rupiah merupakan suatu hal yang paling penting dalam perekonomian.Kurs juga dapat menilai perekonomian suatu negara, dengan memperbandingkan nilai mata uang negara satu dengan negara lainnya. Di dalam perekonomian, nilai tukar mata uang merupakan suatu indikator yang nyata, yang dapat dinilai secara transparan atas apa yang telah terjadi di negara. Misal, negara Indonesia

9 Adiwarman A. karim, Ekonomi Makro Islam, (Jakarta : Raja Grafindo, 2007), hal. 157. 
baru-baru terkenak dampak pada pertukaran nilai mata uang U\$ Dolar, yang mengakibatkan mata uang rupiah melemah.Hal tersebut tentu saja berimbas pada sector perekonomian negara Indonesia, yang mengakibatkan pasar perekonomian Indonesia terpuruk.Tentu saja dalam hal ini, telah terlihat nyata, dan siapa saja dapat melihat tentang keterpurukan perekonomian terhadap nilai tukar mata uang.kajian mengenai resiko nilai tukar terhadap perekonomian perdagangan internasional rupanya semakin banyak menarik perhatian ilmu ekonomi internasional. karena issue pengaruh resiko nilai tukar mempunyai implikasi penting bagi pemilihan sebuah sistem moneter internasional. $^{10}$

Di dalam nilai tukar mata uang atau yang disebut dengan kurs, mempunyai tiga jenis yang sering dikenal di masyarakat, yaitu : ${ }^{11}$

a) Kurs Jual

Kurs Jual adalah kurs yang dikeluarkan oleh bursa valuta asing untuk menjual satu unit mata uang asing tertentu.

b) Kurs Beli

Kurs Beli adalah kurs yang dikeluarkan oleh bursa valuta asing

10 Mahyus Eka nanda, Analisis Pengaruh Volalitas Nilai Tukar Rupiah Pada Ekspor Komoditi Manufaktur Di Indonesia, Buletin Ekonomi Moneter Dan Perbankan, Vol 7, No 2, September 2014, hal. 198

11 Sukwiaty dkk., Perkembangan Perekonomian, (Bandung : Pustaka Setia, 2005), Hal. 25 untuk membeli satu unit mata uang asing tertentu.

c) Kurs Tengah

Kurs Tengah adalah rata-rata dari kurs jual dan kurs beli.Kegunaan kurs tengah adalah untuk menganalisis naik turunnya harga valuta asing di bursa, seperti memperjelas apresiasi dan depresiasi valuta asing tertentu.

Dari beberapa banyak mata uang yang beredar di dunia hanya terdapat beberapa mata uang yang sering dipergunakan sebagai satuan hitung dan banyak dicari dalam transaksi perdagangan dan alat pembayaran internasional.Mata uang yang dimaksud umumnya adalah mata uang yang berasal dari negaranegara maju yang perekonomiannya kuat dan relatif stabil, dan biasanya mata uang tersebut sering mengalami apresiasi dibandingkan dengan mata uang lainnya.Mata uang itu diantaranya adalah Yen-Jepang, USD-AS, Deutchmark-Jerman, Poundsterling-Inggris, dan lainlain.Mata uang yang dimaksud di atas itulah yang sering disebut sebagai Hard Currency. ${ }^{12}$

Berdasarkan sejarah dan perkembangannya, sistem kurs yang pernah ada dan sedang dipraktekkan adalah: ${ }^{13}$

a) Sistem Kurs Tetap (FIER)

\footnotetext{
${ }^{12}$ Iskandar Putong dan ND Andjaswati, Pengantar Ekonomi Makro (Jakarta: Mitra Wacana Media, 2008), h. 154.

${ }^{13}$ Ibid, h. 155 .
} 
Sistem kurs tetap adalah sistem kurs yang mematok nilai kurs mata uang asing terhadap mata uang negara yang bersangkutan dengan nilai tertentu yang selalu sama dalam periode tertentu.

b) Sistem Kurs Mengambang (Floating Exchange Rate)

Sistem kurs mengambang adalah sistem kurs menentukan bahwa nilai mata uang suatu negara ditentukan oleh kekuatan permintaan dan penawaran pada pasar uang. Sistem ini terbagi dua macam yaitu, Clean float (mengambang murni) yaitu apabila penentuan nilai kurs tanpa adanya campur tangan pemerintah. Sedangkan bila pemerintah turut serta mempengaruhi nilai kurs disebut Dirty Float atau kurs mengambang terkendali.

c) Sistem Kurs Terkait (Pegged Exchange Rate)

Sistem kurs terkait adalah nilai tukar yang dikaitkan dengan nilai mata uang negara lain, atau sejumlah mata uang tertentu.

Secara garis besar, sejak tahun 1970, Indonesia telah menerapkan tiga sistem nilai tukar, yaitu sistem nilai tukar tetap pada tahun 1970-1978, sistem nilai tukar mengambang terkendali sejak tahun 1978, dan sistem nilai tukar mengambang bebas sejak 14 Agustus
1997. Dengan diberlakukannya sistem yang terakhir ini, nilai tukar rupiah sepenuhnya ditentukan oleh pasar sehingga kurs yang berlaku adalah benar-benar pencerminan keseimbangan antara kekuatan permintaan dan penawaran.

Dalam pembahasan nilai tukar menurut Islam akan dipakai dua skenario yaitu: ${ }^{14}$

a) Skenario 1: terjadi perubahanperubahan harga di dalam negeri yang mempengaruhi nilai tukar uang (faktor luar negeri dianggap tidak berubah/berpengaruh).

b) Skenario 2: terjadi perubahanperubahan harga di luar negeri (faktor di dalam negeri dianggap tidak berubah/berpengaruh).

Selain dari itu, bahwa kebijakan nilai tukar uang dalam Islam dapat dikatakan menganut sistem "Managed Floating", dimana nilai tukar adalah hasil dari kebijakan-kebijakan pemerintah (bukan merupakan cara atau kebijakan itu sendiri) karena pemerintah tidak mencampuri keseimbangan yang terjadi di pasar kecuali jika terjadi hal-hal yang mengganggu keseimbangan itu sendiri. Jadi bisa dikatakan bahwa suatu nilai tukar yang stabil adalah merupakan hasil dari kebijakan pemerintah yang tepat. ${ }^{15}$

\footnotetext{
Makro.....hal. 168.

${ }^{15} \mathrm{Ibid}$.
} 


\section{Nilai Tukar Uang dalam Persfektif Islam}

Nilai tukar suatu mata uang di dalam Islam di golongkan dalam dua kelompok, yaitu: Natural dan Human. Dalam pembahasan nilai tukar menurut islam akan dipakai dua scenario yaitu: ${ }^{16}$
1) Terjadi perubahan-perubahan harga dalam negeri yang memengaruhi nilai tukar uang. Sebab-sebab fluktuasi sebuah mata uang dikelompokkan sebagai berikut:

a) Natural Exchange Rate Fluctuation

Fluktuasi nilai tukar uang akibat dari perubahan - perubahan yang terjadi pada permintaan agregatif ( $\mathrm{AD}$ ). Expansi AD akan mengakibatkan naiknya tingkat harga secara keseluruhan( $\mathrm{P}$ ), seperti kita ketahui bahwa: $\mathrm{P}=\mathrm{e} \mathrm{P}$, jika tingkat harga dalam negeri naik, sedangkan tingkat harga di luar negeri tetap, maka nilai tukar mata uang akan mengalami depresiasi. Sebalik nya jika AD mengalami kontraksi maka tingkat harga akan mengalami penurunanyang akan mengakibatkan nilai tukar akan mengalami apresiasi.

Fluktuasi nilai tukar uang akibat perubahan-perubahan yang terjadi pada penawaran agregatif (AS). Jika AS mengalami kontraksi, maka akan berakibat pada naiknya tingkat harga secra keseluruhan, yang kemudian akan mengakibatkan

\footnotetext{
${ }^{16}$ Aiwarman A. Karim, Ekonomi Makro...,hal. 167-175
}

melemahnya (depresiasi) nilai tukar. Sebaliknya jika AS mengalami expansi maka akan berakibat pada turunya tingkat harga secara keseluruhan yang akan mengakibatkan menguatnya nilai tukar.

b) Human Error Exchange Rate Fluctuation

Corruption dan Bad Administration yang buruk akan mengakibatkan naiknya harga akibat terjadinya Missallocation of Resources serta Mark-up yang tinggi yang harus dilakukan oleh produsen untuk menutupi biaya-biaya siluman dalam proses produksinya.

Excesssive Tax yang sangat tinggi yang dikenakan pada barang dan jasa akan meningkatkan harga jual dari barang dan jasa tersebut.

Excessive Seignorage, pencetak fullbodyed money atau $100 \%$ reserve money tidak akan mengakibatkan terjadinya inflasi. Akan tetapi jika uang yang dicetak selain dari kedua jenis itu maka akan menyebabkan kenaikan tingkat harga secara umum.

2) Perubahan harga yang terjadi diluar negeri

Perubahan harga yang terjadi diluar negeri bisa digolongkan karena 2 sebab yaitu:

a) Non engineered/ non manifulated changes

Disebut sebagai non eminered/non manifulated changes adalah karena perubahan yang terjadi bukan disebabakan oleh manipulasi (yang dimaksudkan untuk 
merugikan) oleh pihak-pihak tertentu. Misalkan jika bank central singapura (BSS) mengurangi jumlah uang SGD yang beredar, hal tersebut akan mengakibatkan IDR terdepresiasi tanpa diduga. Oleh karena itu BI biasanya akan menghilangkan efek ini dengan menjual SGD yang dimilikinya (cadangan devisa) baik dengan cara strilised intervention maupun dengan cara unsterilized intervention.

b) Enginered/ Manipulated changes

Disebut sebagai enginered/ manipulated changes adalah karena perubahan yang terjadi disebabkan oleh manipulasi yang dilakukan oleh pihak-pihak tertentu yang dimasudkan untuk merugikan pihak lain. misalnya para fund manager disingapura melepas IDR yang dimilikinya sehingga terjadi banjir rupiah yang mengakibatkan nilai tukar rupiah mengalami depresiasai secar tiba-tiba atau drastis diluar perkiraaan BI.

\section{E. Laba}

Tujuan dari sebuah perusahaan adalah memaksimalkan laba keuntungan.Keuntungan atau laba (profit) adalah selisi dari pendapatran di atas biaya-biaya dalam jangka waktu (periode) tertentu. Laba sering digunakan suatu dasar untuk pengenaan pajak, kebijakan deviden, pedoman investasi, serta pengambilan keputusan dan unsure prediksinya. ${ }^{17}$ Laba merupakan keuntungan atau hasil dari perusahaan.Pengertian laba secara operasional merupakan perbedaan antara pendapatan yang direalisasi yang timbul dari transaksi selama satu periode dengan biaya yang berkaitan dengan pendapatn tersebut. Menurut Harahap, laba merupakan angka yang penting dalam laporan keuangan karena laba merupakan dasar dalam perhitungan pajak, pedoman dalam menentukan kebijakan investasi dan pengambilan keputusan, serta dasar dalam peramalan laba maupun kejadian ekonomi perusahaan lainnya di masa yang akan datang.Keuntungan atau laba adalah perbedaan nilai uang dari hasil penjualan yang diperoleh dengan seluruh biaya yang dikeluarkan. ${ }^{18}$

Bila dilihat dari pengertian di atas, laba berarti dapat menghitung atau memprediksikan tentang keadaan perusahaan yang akan datang, dengan begitu para investor yang ingin menginvestasikan uangnya pada suatu perusahaan, harus mengerti terlebih dahulu tentang laba yang ada pada perusahaan tersebut. Jadi, dengan adanya informasi laba pada perusahaan yang dipublikasikan,

17 Junda Adi Wiratama, Pengaruh Informasi Laba, Arus Kas, dan size perusahaan Terhadap Retrun Saham, (jurnal Ilmiah Akuntansi dan Humanikah Jinah), Vol 2, No.1,. Singaraja, Desember 2012, hal. 8

$18 \quad$ Sadono
Ekonomi...,hal. 384 
maka akan mengakibatkan naik turunnya suatu investasi yang ada di dalam perusahaan tersebut. untuk itu, perlunya pempublikasian laba perusahaan pada para calon investor atau masyarakat yang ingin mengetahui tentang laba perusahaan.Laba merupakan informasi penting dalam suatu laporan keuangan

\section{F. Populasi, dan Sampel Penelitian}

Populasi adalah wilayah generelisasi yang terdiri atas obyek/subjek yang mempunyai kualitas dan karakteristik tertentu, yang ditetapkan oleh peneliti untuk dipelajari dan kemudian yang ditarik kesimpulannya. ${ }^{19}$ Sampel adalah wakil-wakil dari populasi. ${ }^{20}$ Dalam penelitian ini populasi yang diambil adalah perusahaan perbankan syariah yang terdaftar di Bank Indonesia.Sedangkan sampel dalam penelitian ini adalah PT. Bank Panin Syariah.

Dalam penelitian ini, data yang digunakan adalah data penelitian sekunder, yang telah dipublikasikan oleh BEI pada situs resminya yaitu www.idx.co.id, Indonesian Capital Market Directory (ICMD), Statistik Ekonomi dan Keuangan yang telah diterbitkan oleh Bank Indonesia.

\footnotetext{
${ }^{19}$ Sugiono, Metode Penelitian Kuantitatif, Kualitatif dan R \& D, (Bandung : Alfabeta, 2013), Hal. 80

${ }^{20}$ Juliandi Azuar, dkk, Metodelogi Penelitian Bisnis, (Medan : UMSU Press, 2014), Hal. 51
}

Serta dari sumber-sumber lain yang dipandang relevan dengan penelitian ini. Penelitian ini menggunakan data tahunan runtut waktu, untuk semua variabel yang digunakan dalam model penelitian.

\section{G. Temuan dan Hasil Pembahasan}

\section{Uji Stasioneritas}

Tabel.2. Hasil Uji ADF

\begin{tabular}{|c|c|c|c|c|}
\hline Variabel & $\begin{array}{c}\text { Unit } \\
\text { Root Test } \\
\text { in }\end{array}$ & $\begin{array}{c}\text { ADF } \\
\text { Test } \\
\text { Statistic }\end{array}$ & $\begin{array}{c}\text { Critical } \\
\text { Value } \\
5 \%\end{array}$ & Ket \\
\hline \multirow{2}{*}{ NTR } & Level & $\begin{array}{r}- \\
8.844526 \\
\end{array}$ & $\begin{array}{r}- \\
3.475305 \\
\end{array}$ & \multirow{2}{*}{$\begin{array}{c}\text { Stasione- } \\
\text { ritas }\end{array}$} \\
\hline & $\begin{array}{l}\text { First } \\
\text { Diference }\end{array}$ & & & \\
\hline \multirow{2}{*}{ LBS } & Level & 8.306258 & $\begin{array}{r}- \\
3.475305\end{array}$ & \multirow{2}{*}{$\begin{array}{c}\text { Stasione- } \\
\text { ritas }\end{array}$} \\
\hline & $\begin{array}{l}\text { First } \\
\text { Diference }\end{array}$ & & & \\
\hline \multirow[b]{2}{*}{ KHS } & Level & $\begin{array}{r}- \\
8.110226 \\
\end{array}$ & $\begin{array}{r}- \\
3.475305 \\
\end{array}$ & \multirow{2}{*}{$\begin{array}{c}\text { Stasione- } \\
\text { ritas }\end{array}$} \\
\hline & $\begin{array}{l}\text { First } \\
\text { Diference }\end{array}$ & & & \\
\hline
\end{tabular}

Sumber : Hasil Olahan Peneliti.

Berdasarkan hasil uji
stasioneritas (ADF) yang telah
ditampilkan oleh peneliti di atas,
maka semua variabel dalam
penelitian ini yaitu NTR, TPJ, LBS
dan KHS adalah stasioneritas pada
tingkat fist dideference pada nilai
kritis $5 \%$.

\section{Uji Lag Optimal}

Tabel.3.Hasil Uji Lag Optimal

\begin{tabular}{|c|c|c|r|r|r|r|}
\hline $\begin{array}{c}\text { L } \\
\text { ag }\end{array}$ & L & LR & FPE & AIC & SC & HQ \\
\hline & - & & 1.33 & 64.5 & 64.7 & 64.6 \\
0 & 2127 & NA & e+23 & 9485 & 2756 & 4729 \\
\hline
\end{tabular}




\begin{tabular}{|c|c|c|c|c|c|c|}
\hline & .63 & & & & & \\
\hline 1 & $\begin{array}{c}- \\
1924 \\
.88\end{array}$ & $\begin{array}{l}374.7 \\
797^{*}\end{array}$ & $\begin{array}{r}4.6 \\
4 \mathrm{e}+2 \\
0 *\end{array}$ & $\begin{array}{c}58 . \\
9357 \\
7^{*}\end{array}$ & $\begin{array}{c}59 . \\
5993 \\
0^{*}\end{array}$ & $\begin{array}{r}59 . \\
1979 \\
7 *\end{array}$ \\
\hline 2 & $\begin{array}{c}- \\
1914 \\
.75\end{array}$ & $\begin{array}{c}17.507 \\
49\end{array}$ & $\begin{array}{r}5.57 \\
e+20\end{array}$ & $\begin{array}{r}59.1 \\
1347\end{array}$ & $\begin{array}{r}60.3 \\
0783\end{array}$ & $\begin{array}{r}59.5 \\
8542\end{array}$ \\
\hline 3 & $\begin{array}{c}- \\
1909 \\
.81\end{array}$ & $\begin{array}{c}7.9328 \\
01\end{array}$ & $\begin{array}{r}7.90 \\
e+20\end{array}$ & $\begin{array}{r}59.4 \\
4864\end{array}$ & $\begin{array}{r}61.1 \\
7383\end{array}$ & $\begin{array}{r}60.1 \\
3035\end{array}$ \\
\hline 4 & $\begin{array}{c}- \\
1903 \\
.64\end{array}$ & $\begin{array}{c}9.1513 \\
32\end{array}$ & $\begin{array}{r}1.09 \\
e+21\end{array}$ & $\begin{array}{r}59.7 \\
4673 \\
\end{array}$ & $\begin{array}{r}62.0 \\
0274 \\
\end{array}$ & $\begin{array}{r}60.6 \\
3819 \\
\end{array}$ \\
\hline 5 & $\begin{array}{c}- \\
1891 \\
.19 \\
\end{array}$ & $\begin{array}{c}16.980 \\
23\end{array}$ & $\begin{array}{r}1.27 \\
\mathrm{e}+21\end{array}$ & $\begin{array}{r}59.8 \\
5424 \\
\end{array}$ & $\begin{array}{r}62.6 \\
4107\end{array}$ & $\begin{array}{r}60.9 \\
5545\end{array}$ \\
\hline 6 & $\begin{array}{c}- \\
1877 \\
.74\end{array}$ & $\begin{array}{c}16.711 \\
97\end{array}$ & $\begin{array}{r}1.47 \\
\mathrm{e}+21\end{array}$ & $\begin{array}{r}59.9 \\
3148\end{array}$ & $\begin{array}{r}63.2 \\
4914\end{array}$ & $\begin{array}{r}61.2 \\
4245\end{array}$ \\
\hline
\end{tabular}

Sumber : Olahan Peneliti.

Berdasarkan uji lag optimal menggunakan krikteria SC, maka peneliti menggunkan lag optimal adalah 1. Seperti yang tertera pada tabel yang telah peneliti tampilkan di atas, dimana criteria kecil dari SC adalah 59.59930 yang terletak pada lag 1.

\section{Uji Stabilitas .}

\begin{tabular}{cc}
\hline \hline Root & $\begin{array}{c}\text { Modul } \\
\text { us }\end{array}$ \\
\hline \hline & 0.970 \\
0.970030 & 030 \\
0.880003 & 0.880 \\
0.836609 & 003 \\
& 0.836 \\
-0.016267 & 609 \\
\hline \hline
\end{tabular}

No root lies outside the unit circle. VAR satisfies the stability condition.

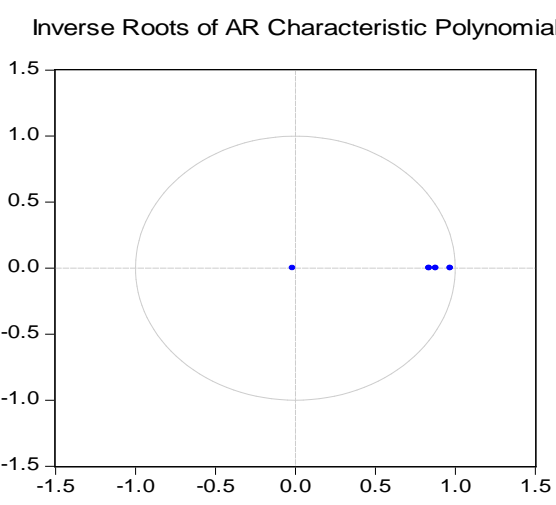

Sumber : Hasil Olahan Peneliti

Dari hasil pengujian stabilitas VAR yang telah dilakukan oleh peneliti, maka peneliti telah mendapatkan hasil dalam mengujian tersebut, bahwa tidak adanya akar unit yang terlihat dari tabel di atas, dimana roots yang telah dihasilkan memiliki modulus lebih kecil dari 1 , dan hal ini juga didukung dari gambar titik invers roots of $\mathrm{Ar}$ Characteristic polynominal yang kesemua variabel berada dalam satu lingkaran. Maka sudah jelas, dari hasil pengjuan yang telah dilakukan oleh peneliti, menunjukan bahwa model VAR sudah stabilitas atau stasioner.

\section{Kasaulitas Granger}

\section{Hasil Uji Kausalitas Granger}

Pairwise Granger Causality Tests

Date: 02/29/16 Time: 15:53

Sample: 2010M01 2015M12

Lags: 1

\begin{tabular}{lccc}
\hline \hline Null Hypothesis: & Obs & $\begin{array}{c}\mathrm{F}- \\
\text { Statistic }\end{array}$ & Prob. \\
\hline \hline $\begin{array}{l}\text { LBS does not Granger } \\
\text { Cause KHS }\end{array}$ & 71 & 13.4805 & 0.0005
\end{tabular}


KHS does not Granger

Cause LBS

$0.22488 \quad 0.6369$

\begin{tabular}{|c|c|c|c|}
\hline NTR does not Granger & & & \\
\hline $\begin{array}{l}\text { Cause KHS } \\
\text { KHS does not Granger }\end{array}$ & 71 & 0.00939 & 0.9231 \\
\hline Cause NTR & & 0.03432 & 0.8536 \\
\hline
\end{tabular}

NTR does not Granger

Cause LBS

LBS does not Granger

Cause NTR

$71 \quad 3.30757 \quad 0.0734$

$0.00029 \quad 0.9864$

TPJ does not Granger

Cause LBS

LBS does not Granger

Cause TPJ

$\begin{array}{lll}71 & 0.17885 & 0.6737\end{array}$

$2.65318 \quad 0.1080$

TPJ does not Granger

Cause NTR

NTR does not Granger

Cause TPJ

$\begin{array}{lll}71 & 1.32369 & 0.2540\end{array}$

$0.44115 \quad 0.5088$

Sumber : Hasil Olahan Peneliti

Adapun pedoman yang diambil untuk melihat tabel hasi uji kausalitas granger adalah jika $\beta_{11} \neq$ 0 dan $\beta_{12} \neq 0$ (nilai $\neq 0$ dan nilai probabilitas $\neq 0$ ) maka $\mathrm{H}_{\mathrm{o}}$ ditolak artinya ada hubungan antar variabel. Sebaliknya jika $\beta_{11}=0$ dan $\beta_{12}=0$ (nilai f-statistik $=0$ dan nilai probabilitas $=0$ ) maka $\mathrm{H}_{0}$ diterima artinya tidak ada hubungan antar variabel. Dari tabel hasil uji kausalitas yang ada di atas, menunjukan bahwa :

1) $\mathrm{H}_{0}$ : LBS tidak ada hubungan kausalitas dengan KHS

$\mathrm{H}_{1}$ : LBS memiliki hubungan kausalitas dengan KHS.

Pengujian granger kausalitas untuk persamaan pertama $\left(\beta_{11}=0\right.$ dan $\beta_{12}=0$ ) terlihat bahwa tidak terjadinya granger causality antara
LBS dan KHS. hal tersebut ditunjukan dengan hasil F-statistik = 13.4805 dan probabilitas $=0.0005$, maka dengan begitu $\mathrm{H}_{0}$ ditolak, yang artinya LBS memiliki hubungan KHS.

2) $\mathrm{H}_{0}$ : KHS tidak ada hubungan kausalitas dengan LBS

$\mathrm{H}_{1}$ : KHS memiliki hubungan kausalitas dengan LBS.

Pengujian granger kausalitas untuk persamaan pertama $\left(\beta_{21}=0\right.$ dan $\beta_{22}=0$ ) terlihat bahwa tidak terjadinya granger causality antara LBS dan KHS. hal tersebut ditunjukan dengan hasil F-statistik = 0.22488 dan probabilitas $=0.6369$ maka dengan begitu $\mathrm{H}_{0}$ ditolak, yang artinya KHS memiliki hubungan LBS.

3) $\mathrm{H}_{0}$ : NTR tidak ada hubungan kausalitas dengan KHS

$\mathrm{H}_{1}$ : NTR memiliki hubungan kausalitas dengan KHS.

Pengujian granger kausalitas untuk persamaan pertama $\left(\beta_{31}=0\right.$ dan $\beta_{32}=0$ ) terlihat bahwa tidak terjadinya granger causality antara NTR dan KHS. hal tersebut ditunjukan dengan hasil F-statistik = 0.00393 dan probabilitas $=0.9231$ maka dengan begitu $\mathrm{H}_{0}$ ditolak, yang artinya NTR memiliki hubungan KHS.

4) $\mathrm{H}_{0}$ : KHS tidak ada hubungan kausalitas dengan NTR 
$\mathrm{H}_{1}$ : KHS memiliki hubungan kausalitas dengan NTR.

Pengujian granger kausalitas untuk persamaan pertama $\left(\beta_{41}=0\right.$ dan $\beta_{42}=0$ ) terlihat bahwa tidak terjadinya granger causality antara KHS dan NTR. hal tersebut ditunjukan dengan hasil F-statistik = 0.03432 dan probabilitas $=0.8536$ maka dengan begitu $\mathrm{H}_{0}$ ditolak, yang artinya KHS memiliki hubungan NTR.

5) $\mathrm{H}_{0}:$ NTR tidak ada hubungan kausalitas dengan LBS

$\mathrm{H}_{1}$ : NTR memiliki hubungan kausalitas dengan LBS.

Pengujian granger kausalitas untuk persamaan pertama $\left(\beta_{71}=0\right.$ dan $\beta_{72}=0$ ) terlihat bahwa tidak terjadinya granger causality antara NTR dan LBS. hal tersebut ditunjukan dengan hasil F-statistik = 3.30757 dan probabilitas $=0.0734$ maka dengan begitu $\mathrm{H}_{0}$ ditolak, yang artinya NTR memiliki hubungan LBS.

6) $\mathrm{H}_{0}$ : LBS tidak ada hubungan kausalitas dengan NTR

$\mathrm{H}_{1}$ : LBS memiliki hubungan kausalitas dengan NTR.

Pengujian granger kausalitas untuk persamaan pertama $\left(\beta_{81}=0\right.$ dan $\beta_{82}=0$ ) terlihat bahwa tidak terjadinya granger causality antara LBS dan NTR. haltersebut ditunjukan dengan hasil F-statistik = 0.00029 dan probabilitas $=0.9864$ maka dengan begitu $\mathrm{H}_{0}$ ditolak, yang artinya LBS memiliki hubungan NTR.

Dapat disimpulkan dari uji kausalitas yang ada di atas, bahwa masing-masing variabel memiliki hubungan dua arah dengan variabel lainnya.

\section{Hasil Uji Impluse Response Function}

Pada sistem model VAR ini juga dapat digunakan untuk melihat dampak perubahan dari satu peubah dalam sistem terhadap peubah lainnya dalam sistem dinamis.Caranya adalah dengan memberikan guncangan(shock) pada salah satu peubah endogen.Guncangan yang diberikan biasanya sebesar satu standart deviasi dari perubahan tersebut (biasanya disebut innovation). ${ }^{21}$

Dari hasil pengujian IRF, jika grafik implus response menunjukan pergerakan yang semakin mendekati titik ke seimbangan (convercen) atau kembali ke keseimbvangan sebelumnya. Hal ini berarti bahwa respon suatu peubah akibat suatu guncangan makin lama akan semakin menghilang sehingga guncangan tersebut tidak meninggalkan pengaruh permanen terhadap peubah tersebut. Adapun hasil dari pengujian IRF peneliti adalah sebagai berikut :

21 Bambang Juanda, \& Junaidi, Ekonometrika Deret Waktu, (Bogor : IPB Press, 2012), hal. 139. 


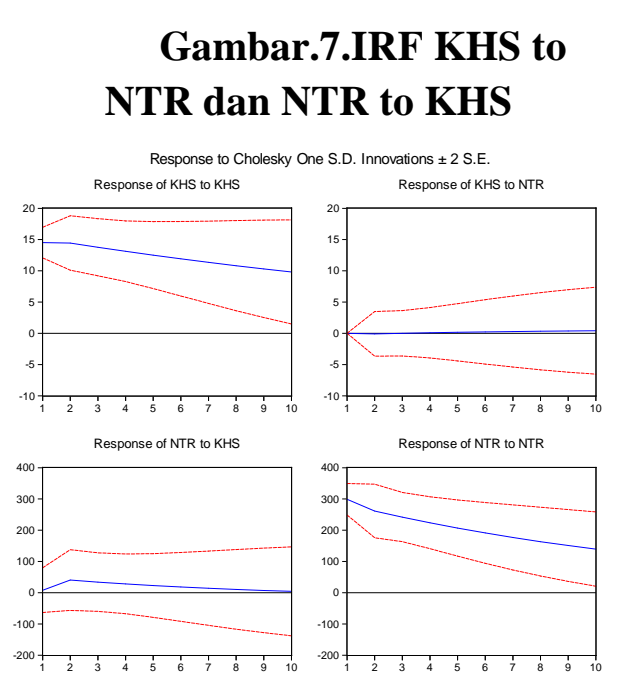

Sumber : Hasil Olahan Peneliti

Dari gambar di atas dapat kita lihat bahwa variabel KHS dalam merespon adanya shock dari variabel NTR pada panel response of KHS to NTR selama 10 bulan, dimana NTR merespon positif dan sangat seimbang dari goncangan KHS sampai ke periode 10. Hal tersebut juga ditunjukan pada tabel Rresponse of NTR to KHS, yang mersespon positif dan seimbang sampai pada periode 10 .

\section{Gambar.8. IRF KHS to LBS dan LBS to KHS}
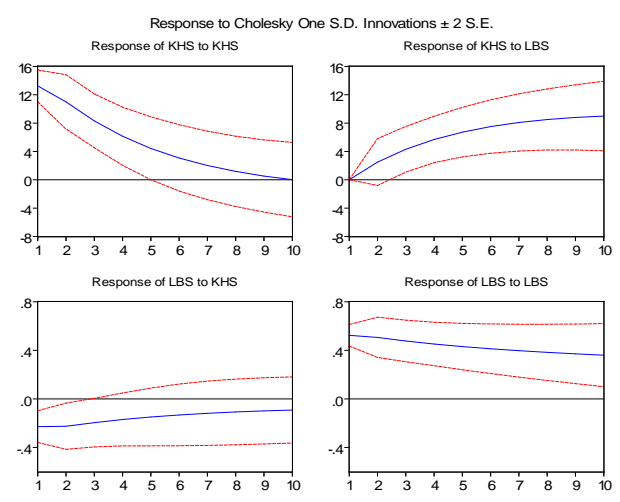

Sumber : Hasil Olahan Peneliti

Pada panel respon of KHS to LBS, menunjukan bahwa LBS merespon positif guncangan KHS, tetapi semakin menjauh dari titik ke seimbangan.Sedangkan pada dalam fanel response of LBS to KHS, terlihat bahwa KHS merespon negative dan mendekati titik ke seimbangan dari guncangan LBS.

\section{Uji Variance Decomposition}

Tabel.4. Variance Decomposition NTR, TPJ, LBS terhadap KHS

\begin{tabular}{|c|c|c|c|c|}
\hline \multicolumn{5}{|c|}{ Variance Decomposition of KHS } \\
\hline Period & S.E. & NTR & LBS & KHS \\
\hline \multirow{2}{*}{ - } & 13.00 & 0.232 & 13.87 & 85.46 \\
\hline & 927 & 211 & 430 & 251 \\
\hline \multirow[b]{2}{*}{2} & 16.65 & 0.278 & 9.334 & 89.92 \\
\hline & 519 & 169 & 562 & 911 \\
\hline \multirow[b]{2}{*}{3} & 18.89 & 0.728 & 7.532 & 91.33 \\
\hline & 822 & 228 & 244 & 111 \\
\hline \multirow[b]{2}{*}{4} & 20.63 & 1.300 & 8.399 & 89.95 \\
\hline & 518 & 883 & 196 & 081 \\
\hline \multirow[b]{2}{*}{5} & 22.17 & 1.783 & 11.35 & 86.56 \\
\hline & 611 & 004 & 230 & 146 \\
\hline \multirow[b]{2}{*}{6} & 23.63 & 2.073 & 15.61 & 82.03 \\
\hline & 365 & 533 & 260 & 319 \\
\hline \multirow[b]{2}{*}{7} & 25.04 & 2.166 & 20.47 & 77.07 \\
\hline & 214 & 208 & 570 & 461 \\
\hline \multirow[b]{2}{*}{8} & 26.40 & 2.108 & 25.42 & 72.15 \\
\hline & 600 & 647 & 791 & 399 \\
\hline \multirow[b]{2}{*}{9} & 27.72 & 1.966 & 30.14 & 67.53 \\
\hline & 054 & 864 & 825 & 029 \\
\hline \multirow[b]{2}{*}{10} & 28.98 & 1.804 & 34.46 & 63.31 \\
\hline & 023 & 020 & 357 & 778 \\
\hline \multirow[b]{2}{*}{11} & 30.18 & 1.671 & 38.29 & 59.54 \\
\hline & 155 & 018 & 897 & 446 \\
\hline \multirow[b]{2}{*}{12} & 31.32 & 1.604 & 41.63 & 56.19 \\
\hline & 337 & 146 & 901 & 290 \\
\hline \multirow[b]{2}{*}{13} & 32.40 & 1.626 & 44.50 & 53.22 \\
\hline & 651 & 098 & 158 & 528 \\
\hline \multirow[b]{2}{*}{14} & 33.43 & 1.748 & 46.92 & 50.59 \\
\hline & 308 & 280 & 178 & 738 \\
\hline \multirow[b]{2}{*}{15} & 34.40 & 1.973 & 48.94 & 48.26 \\
\hline & 597 & 362 & 231 & 562 \\
\hline \multirow[b]{2}{*}{16} & 35.32 & 2.297 & 50.60 & 46.19 \\
\hline & 835 & 648 & 800 & 028 \\
\hline \multirow[b]{2}{*}{17} & 36.20 & 2.713 & 51.96 & 44.33 \\
\hline & 339 & 085 & 275 & 656 \\
\hline
\end{tabular}




\begin{tabular}{|c|c|c|c|c|} 
& 37.03 & 3.208 & 53.04 & 42.67 \\
18 & 413 & 910 & 793 & 465 \\
\hline & 37.82 & 3.772 & 53.90 & 41.17 \\
19 & 334 & 930 & 156 & 932 \\
\hline & 38.57 & 4.392 & 54.55 & 39.82 \\
20 & 350 & 492 & 798 & 927 \\
\hline
\end{tabular}

Sumber : Hasil Olahan Peneliti

Dari hasil uji variance decomposition di atas, dilihat bahwa variasi KHS dipengaruhi oleh KHS itu sendiri pada periode pertama sebesar $85,46 \%$, setelah itu diikuti dengan NTR mempengaruhi KHS sebesar $0,23 \%$, TPJ terhadap KHS sebesar 0,43\%, dan LBS terhadap KHS sebesar 13,87\%. Dalam uji varians decomposition of KHS ini, yang mempunyai variance terbesar adalah LBS sebesar 54,55\%, dan yang mempunyai variance terkecil terhadap KHS adalah NTR sebesar $0,23 \%$ pada periode ke pertama.

\section{H. Kesimpulan}

Dari hasil analisis data yang telah di kemukakan oleh peneliti pada bab-bab sebelumnya, maka dapat diambil kesimpulan dari hasil analisis dengan menggunakan metode VAR yaitu uji Variance Decomposition pada alpha 5\%, dan dengan dibantu dengan program eviews 6, menunjukan bahwa variabel NTR, dan LBS memiliki varian dalam mempengaruhi variabel KHS. Hal tersebut dapat kita lihat dari hasil penelitian. Di awal pengamatan peneliti, variabel Laba bersih atau LBS memiliki pengaruh yang lebih dominan dibanding dengan variabel lainnya, yakni sebesar $13,87 \%$, hal tersebut terus berimbas pada periode-periode selanjutnya sampai pada akhir periode, Laba Bersih tetap menjadi yang dominan dan terbesar dalam mempengaruhi kinerja harga saham bank panin syariah. Sedangkan Nilai Tukar Rupiah atau NTR lebih mempengaruhi KHS. Jadi, hasil penelitian ini dapat dapat disimpulkan, bahwa Laba Bersih dominan mempengaruhi Kinerja Harga Saham atau KHS dalam jangka panjang, sedangkan NTR dan TPJ hanya mempengaruhi biasabiasa saja dibanding dengan Laba Bersih. Untuk menjawab masalah yang telah dikemukakan di awal, maka peneliti membuat hasil penelitian dengan rincian sebagai berikut :

1. Nilai Tukar Rupiah (NTR) memiliki kemampuan dalam mempengaruhi Kinerja Harga Saham (KHS) PT. Bank Panin Syariah sebesar 4,39\%

2. Laba Bersih (LBS) memiliki kemampuan dalam mempengaruhi Kinerja Harga Saham (KHS) PT. Bank Panin Syariah sebesar $54,55 \%$.

3. Dari hasil penelitian di atas, dapat dilihat bahwa pengaruh NTR, dan LBS secara simultan sebesar $60,16 \%$ dan sisanya $39,84 \%$ dipenuhi oleh variabel lainnya yang tidak diuji pada penelitian ini. Pada hasil yang telah di dapat peneliti, bahwa kinerja harga saham Bank Panin 
Syariah di pengaruhi oleh laba bersih sebesar 54,55\%. Hal tersebut berarti, dapat menunjukan bahwa kinerja

\section{Saran}

Berdasarkan hasil analisis yang telah dilakukan oleh peneliti, dan dikarenakan adanya keterbatasan dalam penelitian ini, maka peneliti mengajukan beberapa saran yang nantinya dapat digunakan oleh praktisi maupun akademisi. Adapun beberapa saran yang diajukan oleh penelitiadalah :

1. Untuk penelitian selanjutkan diharapkan menggunakan variabel lain, dan lebih banyak lagi sebagai variabel dependent

\section{Daftar Pustaka}

Departermen Agama Republik Indonesia, Al-Quran dan Terjemahan, Bogor : Sabiq.

Hamzah Ardi, Analisis Rasio Likuiditas, Profitabilitas, Aktivitas, Solvabilitas Dan Investment Oppurtunity Set Dalam Tahapan Siklus Kehidupan Perusahaan Manufaktur Yang Terdaftar Di Busa Efek Jakarta, Jurnal Akuntansi Bisnis, Vol 2, No 2, tahun 2007.

Hasanah Umi Emi, dan Dangan Sunyoto, Pengantar Ilmu Ekonomi Makro, Jakarta : CAPS, 2012. harga saham dipengaruhi oleh laba bersih, dai banding dengan nilai tukar rupiah.

yang mempengaruhi Kinerja Harga saham, dengan menggunakan objek yang berbeda.

2. Penelitian selanjutnya juga dapat mengakaitkan dengan fenomena yang terjadi pada saat meneliti.

3. Karena keterbatasan pengetahuan tentang kinerja harga saham, diharapkan kepada praktisi dan akademisi lebih mensosialisasikan lagi dalam pengenalan harga saham atau asaham itu sendiri

Ismail, Perbankan Syariah, Jakarta : Kencana, 2014.

Juliandi Azua r, dkk, Metodelogi Penelitian Bisnis, Medan : UMSU Press, 2014.

karim Adiwarman A., Ekonomi Makro Islam, Jakarta : Raja Grafindo, 2007.

Mahyus Eka nanda, Analisis Pengaruh Volalitas Nilai Tukar Rupiah Pada Ekspor Komoditi Manufaktur Di Indonesia, Buletin Ekonomi Moneter Dan Perbankan, Vol 7, No 2, September 2014.

Muhammad, Metodologi Penelitian Ekonomi Islam, Jakarta : Rajawali Press, 2008. 
Intiqad Vol. 8 No. 2 Desember 2016: 84 -100

N. Gregeory mankiw, Pengantar Ekonomi, Jakarta : Erlangga, 2000.

R. Serfianto dan D. Purnomo, Pasar Uang Dan Pasar Vals, Jakarta : Gramedia Pustaka Utama, 2013.

Sugiono, Metode Penelitian Kuantitatif, Kualitatif dan R \& D, Bandung : Alfabeta, 2013

Triyono, Analisis Perubahan Kurs Rupiah Terhadap Dollar Amerika. Jurnal Ekonomi Pembangunan. Vol 9, No.2, 2008.

Wawancara dengan Pengamat Ekonomi SUMUT, di Reksa Dana, pada tanggal 14 oktober 2015.

Wiratama Adi Junda, Pengaruh Informasi Laba, Arus Kas, dan size perusahaan Terhadap Retrun Saham, (jurnal Ilmiah Akuntansi dan Humanikah Jinah), Vol 2, No.1,. Singaraja, Desember 2012. 